\title{
Palaeomagnetic evidence for non-rotational deformation along the Nea Anchialos Fault System, Central Greece
}

\author{
Despina Kondopoulou $\left({ }^{1}\right)$ and Riccardo Caputo $\left({ }^{2}\right)$ \\ $\left.{ }^{1}{ }^{1}\right)$ Department of Geology, Aristotle University of Thessaloniki, Greece \\ ${ }^{2}$ ) Dipartimento di Scienze della Terra, Università G. D'Annunzio, Chieti Scalo, Italy
}

\begin{abstract}
Four sites in 1.4 Ma old basaltic lavas and two sites in upper Pliocene-lower Quaternary sediments, located both in the hanging-wall and in the footwall blocks of the Nea Anchialos Fault System, have been sampled. This fault system is one of the major E-W trending structures affecting the Thessaly region during Quaternary times. It is possibly connected with the North Aegean Trough to the E and displays recent seismic activity (1980, Volos earthquake). Standard techniques have been used for both field sampling and laboratory analyses. The magnetic carriers were characterised by measuring the thermomagnetic curves, the anisotropy of magnetic susceptibility and the isothermal remanent magnetisation of the samples. Almost all the samples exhibit a reverse polarity. The overall mean palaeomagnetic direction is defined by $D=174^{\circ}, I=-54^{\circ}$, confirming the non-rotational deformation pattern of the Nea Anchialos Fault System as independently inferred from structural investigations.
\end{abstract}

Key words palaeomagnetism - fault - deformation - Central Greece

\section{Introduction}

Following the detailed structural investigation of the Nea Anchialos Fault System (here on referred to as NAFS, fig. 1) which is reported in a companion paper (Caputo, 1996), a palaeomagnetic research has been performed to detect possible regional and/or local rotations occurring within the area as a consequence of the intense tectonic activity during Quaternary times. Indeed, the NAFS is a key area in order

Mailing address: Dr. Riccardo Caputo, Via A. Lollio 7, 44100 Ferrara, Italy; e-mail: caputo@unich.it to understand the complex geodynamics of the whole Northern Aegean region as, within continental Greece, the NAFS lies exactly along the geometrical prolongation of the North Aegean Trough along which mainly obliqueslip and strike-slip motion was inferred from focal mechanisms (e.g., Voidomatis, 1984; Papazachos et al., 1991). On the other hand, to the east, the North Aegean Trough is directly connected with the North Anatolian Fault where a pure right-lateral strike-slip motion is documented (e.g., Jackson and McKenzie, 1984). The existence of this tectonic paradox within the Northern Aegean region, has recently been emphasised by Pavlides and $\mathrm{Ca}$ puto (1994).

Caputo (1990) showed that the recent tectonics (late Pleistocene-Present) of the whole Thessaly region (Central Greece) has been mainly taken up by a series of E-W to 


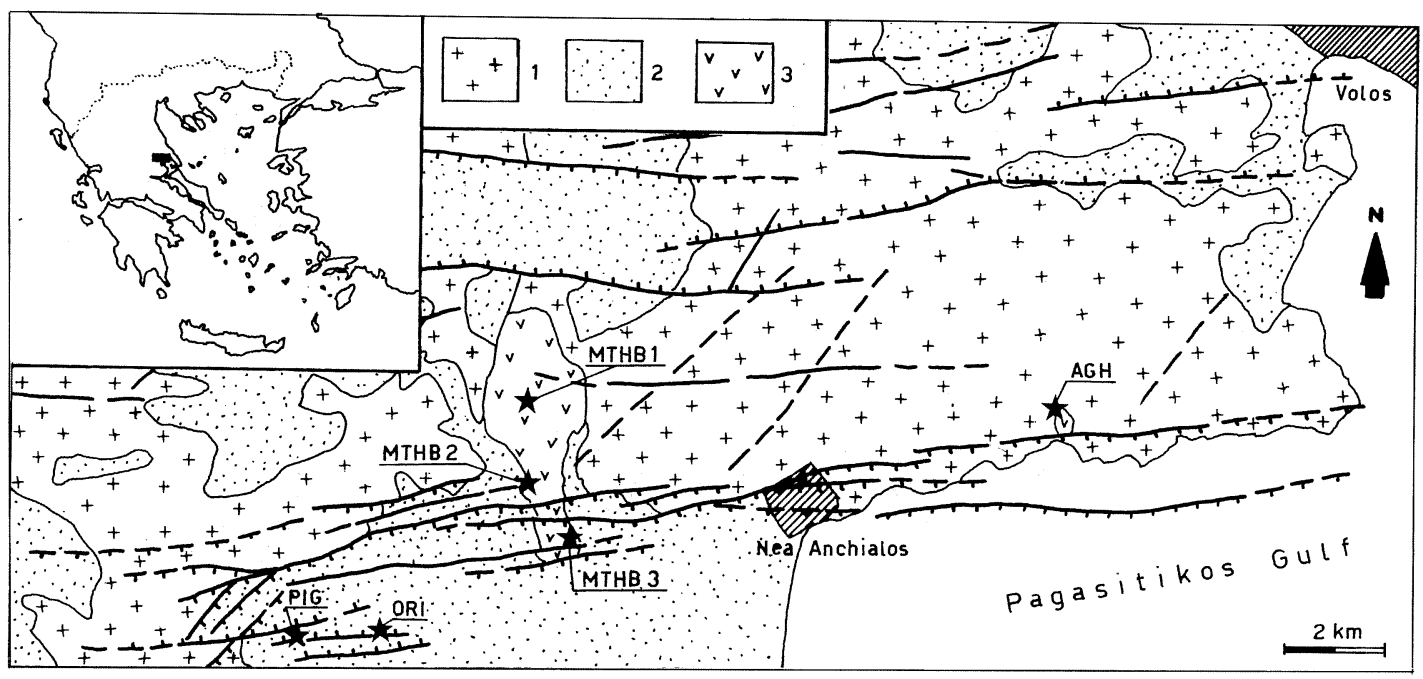

Fig. 1. Schematic geological and tectonic map of the study area (from Caputo, 1996). 1) Undifferentiated Palaeozoic to Mesozoic rocks; 2) Pliocene-Quaternary deposits; 3) Mikrothive volcanics. Stars represent sites of palaeomagnetic sampling; labels correspond to table I.

ESE-WNW trending normal faults, associated with a pure N-S extension. No strike-slip movements have been recorded and both structural and seismological data indicate that the NAFS is a pure dip-slip normal structure. Oblique-slip motion was observed only on minor fault planes of the system, the horizontal component that can be inferred is left-lateral, that is opposite to that of the North Anatolian Fault-North Aegean Trough tectonic system.

In continental Greece, several palaeomagnetic researches were carried out during the last two decades (e.g., Kissel et al., 1985; Marton et al., 1990; Westphal et al., 1991; Morris, 1995; Kondopoulou, 1996) and have shown a general pattern of prevailing clockwise rotations from the Oligocene to the Present (Kissel and Laj, 1988; Kondopoulou, 1993). However, in Central Greece, Plio-Quaternary palaeomagnetic data are few and limited to four sites in Southern Magnesia and two in Northern Evia (Kissel et al., 1986).

The aim of the present research is to detect whether rotations have occurred within this key area in recent times. In fact, crustal rotations induced by strike-slip faulting are very common globally (Luyendyk et al., 1980; Ron et al., 1984) and the estimate of their magnitude would be a particularly crucial parameter to understand the recent crustal evolution of Central Greece.

\section{Geological framework}

The NAFS is one of the major active tectonic features of the Thessaly region (Caputo, 1995). Although its geometry at the surface is quite complex in detail, on a crustal scale this structure can be simply described as a dip-slip south-dipping normal fault. Its cumulative vertical offset is probably of few hundred metres. According to stratigraphic, structural, morphotectonic, archaeological and seismological data the NAFS has been clearly active throughout Quaternary times and up to the Present $(\mathrm{Ca}-$ puto, 1996). Several lithologies are affected along its entire length. The investigation was concentrated on the western sector where mainly metamorphic and non-metamorphic formations of Palaeozoic and Mesozoic age crop out within the footwall block and 
Pliocene-Quaternary deposits are largely represented within the hanging-wall (fig. 1). Within the study area, basaltic rocks crop out near the village of Mikrothive, from a few metres up to $20 \mathrm{~m}$ thick (Frankopoulos, 1956), probably consisting of few N-S trending lava flows. The volcanics were radiochronologically dated at $1.4 \pm 0.1 \mathrm{Ma}$ (Innocenti et al., 1979). These volcanic rocks, known as the Thive Formation, are clearly affected by the NAFS, creating a step-like structure (fig. 2). Another small outcrop is reported east of Nea Anchialos along the road to Volos, where the cone-like geometry and the mixing of these basalts with a breccia of the substratum rocks suggests an aborted effusive centre.

In the downthrown southern block of the NAFS, the Pliocene-lower Pleistocene fluvio- lacustrine sediments of the Almyros Formation (Caputo, 1990) largely crop out (fig. 1). This stratigraphic sequence, several tens of metres thick, is characterised by frequent lateral and vertical facies variations, with interfingering of different lithological units. The main lithologies are brownish-reddish breccias and sandstones (probably slope debris deposits), which are mainly in the northern sector (i.e, closer to the source area) and in the lowermost stratigraphic levels. Southwards and upwards, these sediments grade into white and yellowish marls locally interbedded with fine-grained clastic layers deposited in a fluvio-lacustrine palaeo-environment. These deposits are generally in normal tectonic contact with the Alpide substratum and only locally it is possible to map a stratigraphic contact. Unconformably

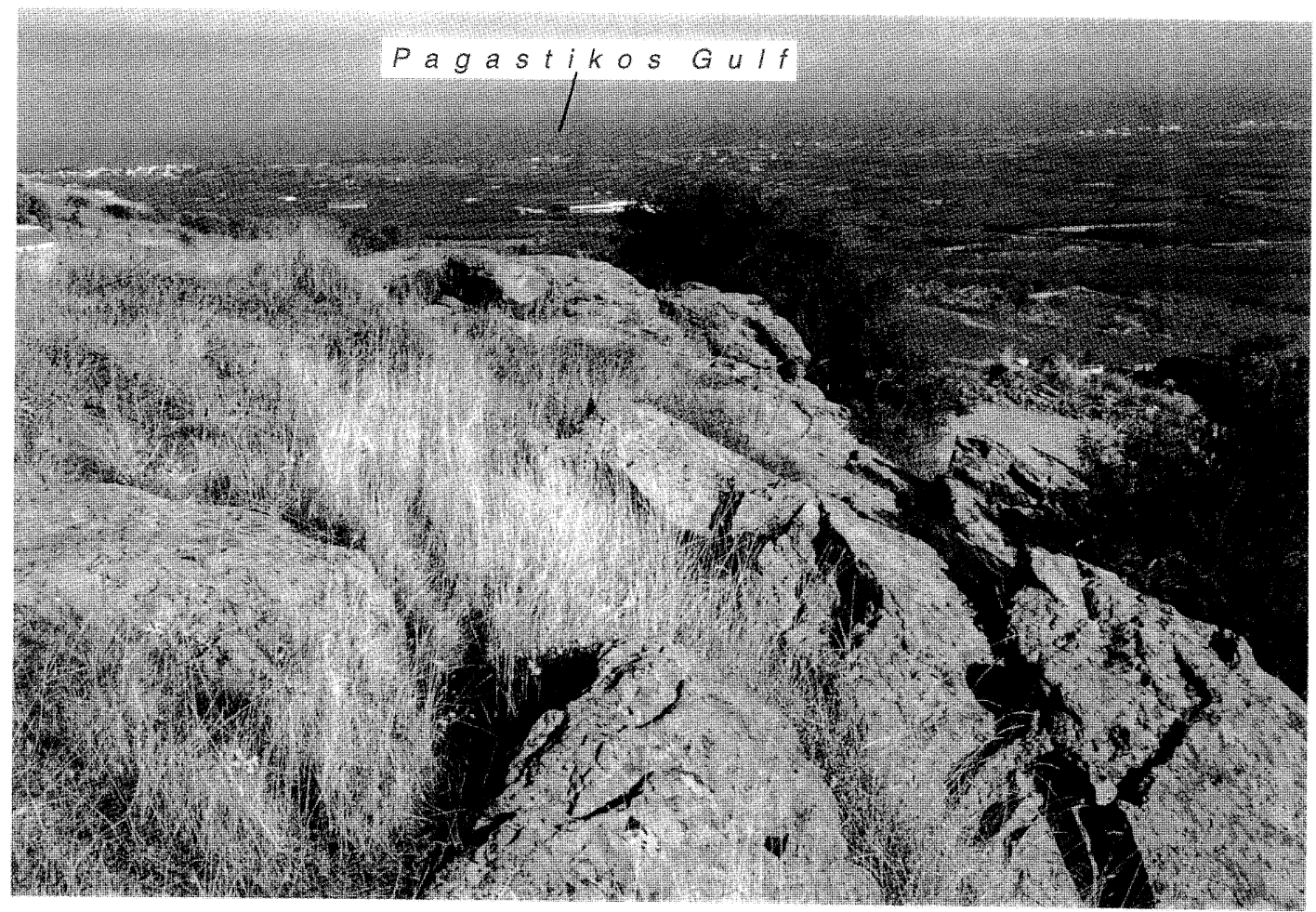

Fig. 2. Basaltic lava flows of the Thive volcanic Formation seen from site MTHB3, located at the southern border of the footwall block of the NAFS. In the far field, looking toward ESE, the Quaternary Almyros basin characterised by the Almyros plain and the Pagasitikos Gulf is also visible. The difference in level is noteworthy. 
above the Almyros Formation, Red Beds type deposits rest. These sediments, consisting of poorly cemented clastic materials with variable grain-size and abundant matrix, were tentatively dated as late Pleistocene (Caputo, 1996). Both the Almyros Formation and the Red Beds are diffusely affected by faulting and often deeply entrenched by streams crossing the footwall blocks. Loose clastic fine-grained sediments are widely distributed in the Almyros plain where they show a clear onlap contact along the foothills south of the fault system as well as along some of the major streams. Due to their stratigraphic position, a latest PleistoceneHolocene age can be tentatively inferred.

\section{Palaeomagnetic sampling and results}

Four sites have been sampled in the Thive volcanic Formation and two sites in the middle layers of the Almyros Formation (fig. 1). A total of 60 standard $25 \times 22 \mathrm{~mm}$ cylindrical specimens have been obtained. The remanent magnetisation of all specimens was measured with a Molspin magnetometer. The NRM values are sufficiently high for a palaeomagnetic study, ranging from 10 to $40 \mathrm{~mA} / \mathrm{m}$ for the sediments and from 15 to $800 \mathrm{~mA} / \mathrm{m}$ for the basalts.

Firstly, a set of 18 pilot specimens were demagnetised using the AF shielded demagnetiser at the University of Thessaloniki. In about $40 \%$ of the samples, particularly the lavas, this process is not satisfactory as an important amount of magnetisation $(\sim 30 \%)$ remains after the highest capacity of the instrument has been reached $(95 \mathrm{mT})$. Nevertheless, in 15 cases a stable direction could be defined (fig. 3a-c). Subsequently, 28 specimens from lavas and sediments were demagnetised, by stepwise heating up to temperature ranges of $450^{\circ}-685^{\circ} \mathrm{C}$, at the Universities of Strasbourg and Utrecht.

As far as the volcanic rocks are concerned, unblocking temperatures rarely exceed $600^{\circ} \mathrm{C}$ but in almost all cases a stable component, directed towards the origin, could be easily defined. The viscous magnetisation is easily removed between $20^{\circ}$ and $200^{\circ} \mathrm{C}$ (fig. 4a). In contrast, the unblocking temperature range for

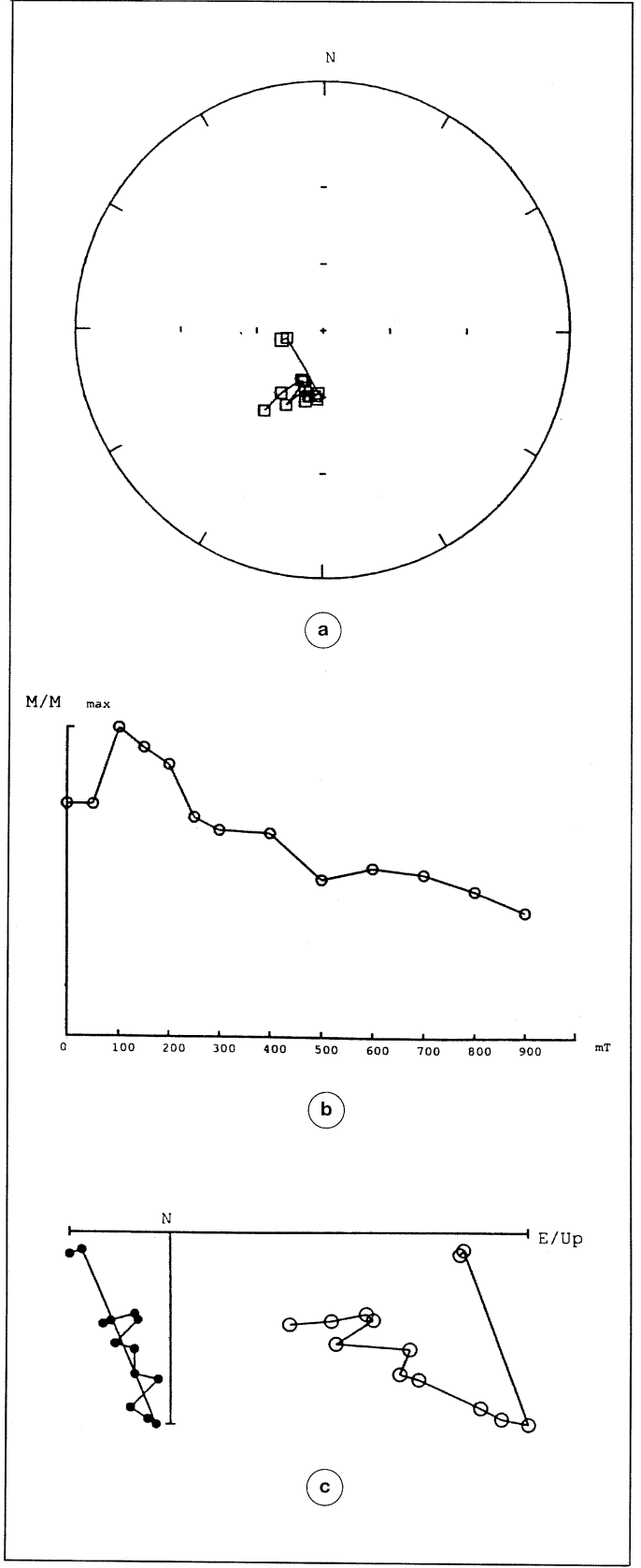

Fig. 3a-c. Example analysis showing (a) the evolution of the direction, (b) the normalised intensity and (c) the component analysis for a lava site (MTHB1), during AF demagnetisation. 

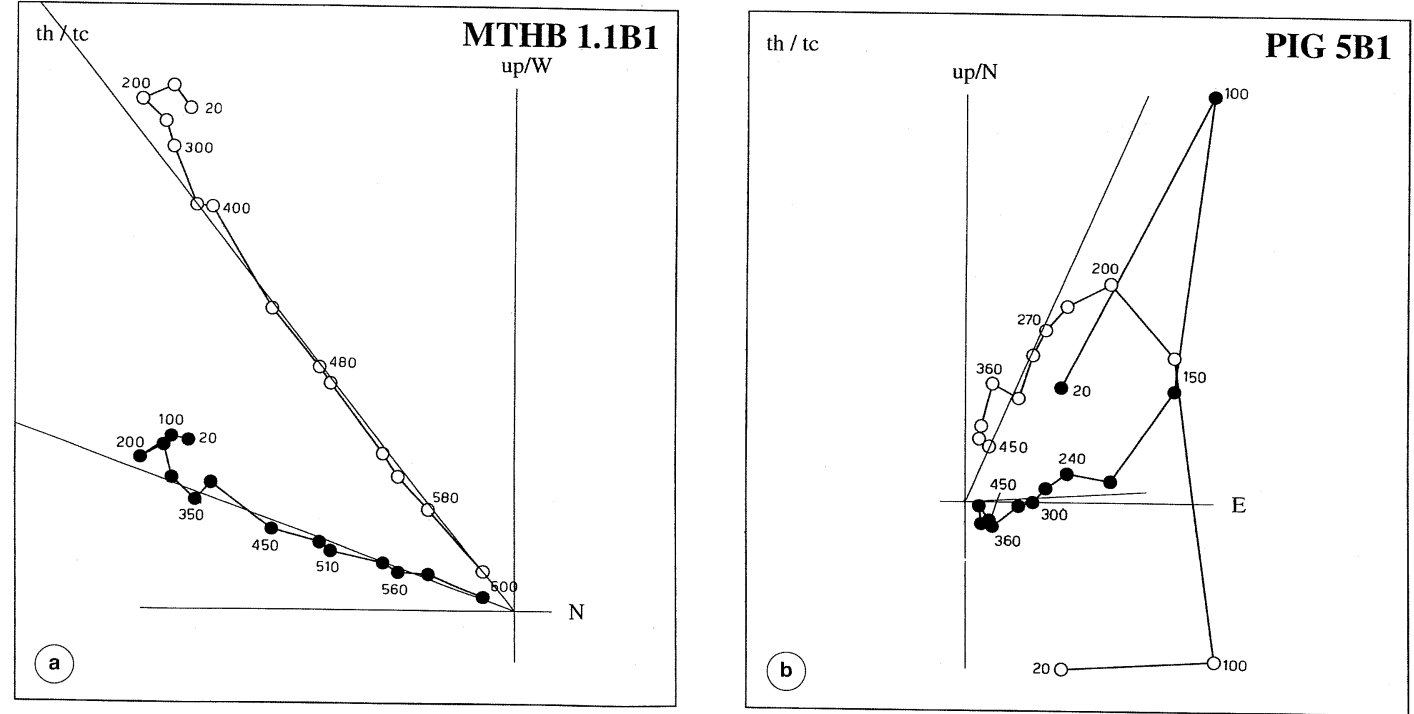

Fig. 4a,b. Typical thermal demagnetisation diagram (a) of a lava sample (site MTHB1) and (b) of a sediment sample (site PIG). Full and open circles represent the projections onto the horizontal and the vertical planes, respectively. Numbers represent temperature steps during heating.

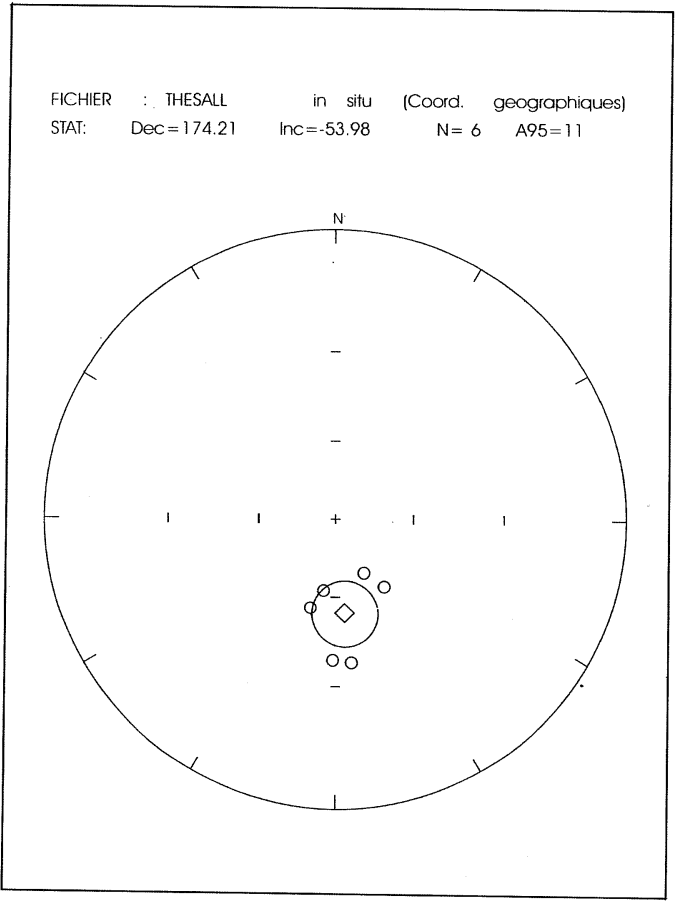

Table I. Palaeomagnetic mean site directions.

\begin{tabular}{lccccc}
\hline \hline \multicolumn{1}{c}{ Site } & $N$ & $D$ & $I$ & $k$ & $\alpha_{95}$ \\
\hline MTHB1 & 7 & $196^{\circ}$ & $-55^{\circ}$ & 125 & $4.7^{\circ}$ \\
MTHB2 & 6 & $152^{\circ}$ & $-66^{\circ}$ & 14 & $16.2^{\circ}$ \\
MTHB3 & 5 & $181^{\circ}$ & $-38^{\circ}$ & 17 & $15^{\circ}$ \\
AGH & 7 & $190^{\circ}$ & $-62^{\circ}$ & 374 & $2.7^{\circ}$ \\
PIG & 6 & $173^{\circ}$ & $-37^{\circ}$ & 15 & $16.3^{\circ}$ \\
ORI & 7 & $144^{\circ}$ & $-58^{\circ}$ & 12 & $16.6^{\circ}$ \\
\hline
\end{tabular}

Fig. 5. Equal area projection, upper hemisphere, of the site-mean directions of magnetisation (circles) and of the mean palaeomagnetic direction from all the sites (rhomb). The larger circle represents the uncertainty at the $95 \%$ confidence level. 
the sediments was lower $\left(420^{\circ}-450^{\circ} \mathrm{C}\right)$ and in 5 out of 12 samples a stable component was either impossible to define or, when possible, had an extremely low inclination of about $6^{\circ}$ (fig. 4b). No tilt correction was applied since sediments were practically horizontal. The over- all mean directions of each site are listed in table I and in the stereographic projection of fig. 5.

In order to investigate the reliability of the calculated stable component, rock magnetic measurements were performed at the laboratory of the Academy of Sciences of Warsaw.

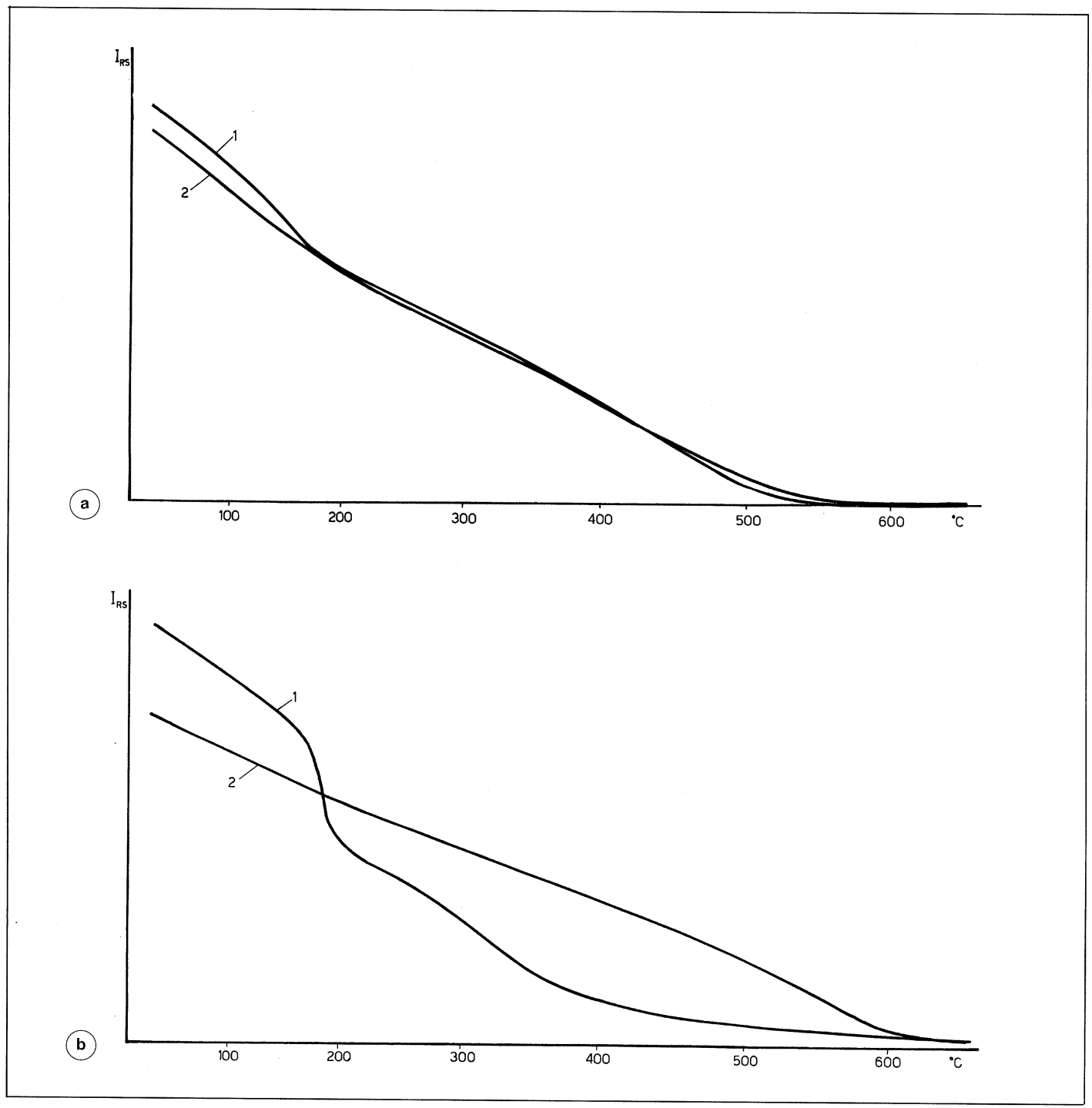

Fig. 6a,b. Examples of thermomagnetic analyses (a) for a lava sample containing magnetite and (b) for a sediment where maghemite transforms to hematite. 1) first heating curve; 2) second heating curve. 
First, thermomagnetic curves were obtained which provide information on the magnetic carriers and possible mineralogical transformations during heating (fig. 6a,b). According to these results, Curie temperatures are below $600^{\circ} \mathrm{C}$ for lavas (fig. 6a). In the sediments, two different Curie temperatures are observed before and after heating, around $525^{\circ} \mathrm{C}$ and $650^{\circ} \mathrm{C}$, respectively, with a magnetic phase at $200^{\circ} \mathrm{C}$ (fig. 6b). When combined to the maximum unblocking temperatures observed during thermal demagnetisation, it is possible to infer that the volcanic rocks contain mainly magnetite, while the sediments contain maghemite which was transformed into hematite during heating. An IRM test performed on pilot samples has partially confirmed the above assumption. Nevertheless, the majority (3 out of 4 ) of IRM curves from lavas and 2 out of 3 from the sediments are saturating in the fields between 0.2 and $0.5 \mathrm{~T}$ (fig. 7a,b).

Finally, the anisotropy of magnetic susceptibility was measured. For sediments $(N=5)$, the anisotropy factor, $P$, varies between 1.009 and 1.015. This gives percentages between $0.9 \%$ and $1.5 \%$, thus confirming their general isotropy. In contrast, the anisotropy factor for lavas $(N=6)$, varies between $1.006(\mathrm{AGH})$ to 1.054 (MTHB2), thus implying percentages between $0.6 \%$ and $5-4 \%$. Indeed, 5 out of 6 samples reach significant levels. Lavas are in general more anisotropic than sediments which is usually not the case.

It is noteworthy that the polarities obtained from the sediments are mostly reverse with a very few normal ones which are almost antiparallel. This confirms that a satisfactory magnetic cleaning was obtained. All samples from volcanic rocks yielded reverse directions. The same reverse directions $\left(D=178^{\circ}\right.$, $I=-59^{\circ}$ ) were obtained in a previous study (Kissel et al., 1986) in a different lava flow, approximately $50 \mathrm{~km}$ south of the present study area and of a different age (3 Ma). According to the almost N-S declination values, no rotations can be detected, while the inclination values are close to the expected ones for the investigated area clearly indicating that no important tilt has occurred.

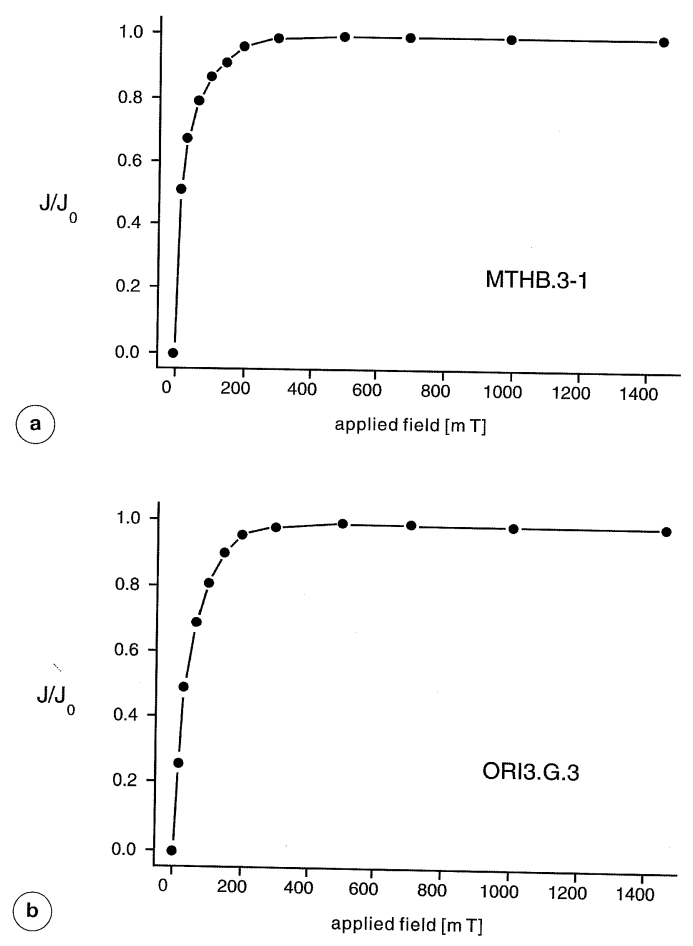

Fig. 7a,b. Representative IRM acquisition curves (a) for a lava sample and (b) for sediment sample.

\section{Concluding remarks}

From a structural point of view, the fact that the palaeomagnetic results indicate no rotation, supports the lack of any strike-slip motion along the NAFS during Quaternary times (fig. 5). Due to the geodynamic context of the broader Northern Aegean region (e.g., Pavlides and Caputo, 1994), the lack of such transcurrent movements along the NAFS can probably be extended back to the Pliocene. These results, independently from the structural investigation (Caputo, 1990, 1996), thus confirm that no strike-slip movements have occurred along the NAFS or, if any, they have been of limited importance. Consequently, the bulk of deformation is associated to dip-slip normal faulting. Furthermore, the distribution of the sites, both in the footwall and in hanging-wall blocks 
Table II. Palaeomagnetic results of previous works from Central and Western Greece for ages younger than 5 Ma.

\begin{tabular}{llrrl}
\hline \hline \multicolumn{1}{c}{ Site } & \multicolumn{1}{c}{ Age } & \multicolumn{1}{c}{$D$} & \multicolumn{1}{c}{ References } \\
\hline N. Evia & Lower Pliocene-early Pleistocene & $236^{\circ}$ & $-30^{\circ}$ & Kissel et al. (1986) \\
Attica & Pliocene & $26^{\circ}$ & $52^{\circ}$ & Morris (1995) \\
Zakynthos & Pliocene-Quaternary & $184^{\circ}$ & $-57^{\circ}$ & Laj et al. (1982) \\
Kefallinia & Pliocene & $9^{\circ}$ & $53^{\circ}$ & Laj et al. $(1982)$ \\
\hline
\end{tabular}

(fig. 1), and the pattern of the obtained inclinations confirm the absence of detectable tilting associated with the faulting. According to $\mathrm{Pa}-$ pazachos et al. (1983), this crustal-scale structure has a listric shape and assuming a mean radius of $10-15 \mathrm{~km}$ the theoretical tilting in the hanging-wall block due to the movement, can be calculated as less than $3^{\circ}$, much less than the accuracy of the palaeomagnetic method.

These new results can be compared with those previously obtained in Central and Western Greece for ages younger than $5 \mathrm{Ma}$ (table II). The inconsistency between present and past directions from the Volos area and the Northern Evia sites, indicating clockwise rotation, has been attributed by Kissel et al. (1986) to the existence of a shear zone crossing the gulf between mainland Greece and Evia Island. In contrast, palaeomagnetic results from the nearby Achilleon lavas, Southern Magnesia (Kissel et al., 1986), do not indicate rotation or tilting. Though the age of the latter sampled rocks is even older ( $3 \mathrm{Ma}$ ) than the Thive volcanic formation, their results agree well with our observations along the NAFS.

Moreover, there is a remarkable consistency between the presented results and those obtained from Zakynthos and Kefallinla islands (Laj et al., 1982) where a non-rotational pattern has also been detected in Pliocene and Quaternary sediments. According to Le Pichon et al. (1995, fig. 6a,b), both areas (i.e, Ionian Islands and NAFS) belong to a zone included within the isovelocity lines of 20 and $25 \mathrm{~mm} / \mathrm{yr}$ and thus can be considered transitional between the counter-clockwise rotating block of Anatolia to the south, and the clockwise rotating Northern Greece, to the north.
As a final comment, the need for further palaeomagnetic research within the study area is stressed as well as in the broader Southern Thessaly and Magnesia regions. In fact, though the reliability of these new results is confirmed by the small $\alpha_{95}$ angle and the perfect agreement with the geometry and kinematics of the NAFS, new palaeomagnetic data would consolidate the inferred overall geodynamic pattern, while the investigation and sampling of Pliocene deposits outcropping in nearby areas would provide information for longer time periods.

\section{Acknowledgements}

We wish to thank $\mathrm{Ph}$. Voidomatis and El. Aidona for their help in laboratory measurements in Thessaloniki and Utrecht Universities. C. Langereis is warmly acknowledged for providing facilities in the palaeomagnetic laboratory of Utrecht; H. Haubold (Gams, Austria) for providing the IRM acquisition curves and M. Jelenska for her help in obtaining the thermomagnetic curves in the Warsaw Academy of Sciences. Comments from D.H. Tarling and F. Speranza improved a previous version of the manuscript. Financial support has been provided by B.C. Papazachos through an EU EPOC (contract \# CT91-0042).

\section{REFERENCES}

CAputo, R. (1990): Geological and structural study of the recent and active brittle deformation of the NeogeneQuaternary basins of Thessaly (Central Greece), Ph.D. Thesis, University of Florence, Sci. Ann. Aristotle University of Thessaloniki, 12, 2 vols., 1-252. 
CAPUTO, R. (1995): Inference of a seismic gap from geological data: Thessaly (Central Greece) as a case study, Ann. Geofis., 38, 1-19.

CAPUTO, R. (1996): The active Nea Anchialos Fault System (Central Greece): comparison of geological, morphotectonic, archaeological and seismological data, Ann. Geofis., 39, 557-574.

FRANKOPOULOS, I.A. (1956): Petrologiki meleti ton lavon tou ifaisteiou ton Thivon en Thessalia, Ph.D. Thesis, University of Athens, pp. 59 (in Greek).

Innocenti, F., P. Manetti, A. Peccerillo and G. Poli (1979): Inner arc volcanism in NW Aegean arc: geochemical and geochronological data, N. Jb. Miner. Mh. 4, 145-158.

JACKSON, J. and D. MCKENZIE (1984): Active tectonics of the Alpine-Himalayan Belt between Western Turkey and Pakistan, Geophys. J. R. Astron. Soc., 77, 185-264.

KISSEL, C. and C. LAJ (1988): The tertiary geodynamic evolution of the Aegean arc: a paleomagnetic reconstruction, Tectonophysics, 146, 183-201.

Kissel, C., C. LAJ and C. Muller (1985): Tertiary geodynamic evolution of Northwestern Greece: paleomagnetic results, Earth Planet. Sci. Lett., 72, 190-204.

KIssel, C., C. LAJ and A. MAzaud (1986): Paleomagnetic results from Neogene formations in Evia, Skyros and the Volos region and the deformation of Central Aegean, Geophys. Res. Lett., 13, 1446-1449.

Kondopoulou, D. (1993): Paleomagnetism in Greece and geodynamic implications: a review of data from Paleozoic, Mesozoic and Cenozoic formations, in 2nd Congress Hellenic Geophysical Union, Florina, May 5-7, 1993, Proceedings, 2, 550-577.

Kondopoulou, D. (1996): Some constraints on the origin and timing of magnetization for Mio-Pliocene sediments from Northern Greece, Bull. Geol. Soc. Greece, 30 (in press).

LaJ, C., M. Jamet, D. Sorel and J.-P. Valente (1982): First paleomagnetic results from Mio-Pliocene series of the Hellenic sedimentary arc, Tectonophysics., 86, 45-67.

Le Pichon, X., N. Chamot-Rooke, S. Lallemant, R.
NOOMEN and G. VEIS (1995): Geodetic determination of the kinematics of Central Greece with respect to $\mathrm{Eu}$ rope: implications for Eastern Mediterranean tectonics, J. Geophys. Res., 100 (B7), 12675-12690.

LUYENDYK, B.P., M.G. KAMERLING and R.R. TERRES (1980): Geometric model for Neogene crustal rotations in Southern California, Geol. Soc. Am. Bull., 91, 211-217.

Marton, E., D.J. Papanikolaou and E. LekKas (1990): Paleomagnetic results from Pindos, Paxos and Ionian zones of Greece, Phys. Earth Planet. Int., 62, 60-69.

MorRIS, A. (1995): Rotational deformation during Palaeogene thrusting and basin closure in Eastern Central Greece: palaeomagnetic evidence from Mesozoic carbonates, Geophys. J. Int., 121, 827-847.

Papazachos, B.C., D.G., Panagiotopoulos, T.M., TSAPANOS, D.M. Mountrakis and G.C. Dimopoulos (1983): A study of the 1980 summer seismic sequence in the Magnesia region of Central Greece, Geophys. J. R. Astron. Soc., 75, 155-168.

Papazachos, B.C, A.A. Kiratzi and E.E. Papadimitriou (1991): Regional focal mechanism for earthquakes in the Aegean area, Pageoph, 136, 305-332.

PAVlides, S. and R. CAPUTO (1994): The North Aegean Region: a tectonic paradox? Terra Nova, 6 (1), 37-44.

Ron, H., R. Freund, Z. Garfunkel and A. Nur (1984): Block rotation by strike-slip faulting: structural and paleomagnetic evidence, J. Geophys. Res., 39, 62566270 .

VoIdomatis, P. (1984): Seismicity of Northern Greece and surrounding area, Ph.D. Thesis, Aristotle University of Thessaloniki, pp. 201.

Westphal, M., D. Kondopoulou, J.B. Edel and S. PAVLIDES (1991): Paleomagnetism of late Tertiary and Plio-Pleistocene formations from N. Greece, Bull. Geol. Soc. Greece, 25 (3), 239-250.

(received September 3, 1996; accepted June 27, 1997) 